\title{
Tregalizumab - A Monoclonal Antibody to Target Regulatory T Cells
}

\author{
Martin König*, Faiza Rharbaoui, Silke Aigner, Benjamin Dälken ${ }^{\dagger}$ and Jörg Schüttrumpf ${ }^{\dagger}$ \\ Biotest AG, Dreieich, Germany
}

Regulatory $T$ cells (Tregs) represent a subpopulation of CD4+ $T$ cells, which are essential for the maintenance of immunological tolerance. The absence or dysfunction of Tregs can lead to autoimmunity and allergies. The restoration of functional Tregs and/or Treg cell numbers represents a novel and attractive approach for the treatment of autoimmune diseases, e.g., rheumatoid arthritis (RA). The CD4 cell surface receptor is a target for modulation of $T$ cell function. Monoclonal antibodies (mAbs) against CD4 have previously

OPEN ACCESS

Edited by:

Tobias Bopp,

University Medical Center Mainz,

Germany

Reviewed by:

Jagadeesh Bayry,

Institut National de la Santé et de la

Recherche Médicale (INSERM),

France

Daniel Olive,

Institut National de la Santé et de la

Recherche Médicale (INSERM),

France

*Correspondence:

Martin König

martin_koenig@biotest.de

${ }^{\dagger}$ Benjamin Dälken and Jörg Schüttrumpf contributed equally.

Specialty section: This article was submitted to Immunotherapies and Vaccines,

a section of the journal

Frontiers in Immunology

Received: 21 October 2015

Accepted: 11 January 2016

Published: 25 January 2016

Citation:

König M, Rharbaoui F, Aigner S, Dälken B and Schüttrumpf J (2016)

Tregalizumab - A Monoclonal Antibody to Target Regulatory

$T$ Cells.

Front. Immunol. 7:11. doi: 10.3389/fimmu.2016.00011 been tested for the treatment of autoimmune diseases, including RA. Furthermore, in model systems, anti-CD4 antibodies are able to induce tolerance and mediate immunomodulatory effects through a variety of mechanisms. Despite the availability of innovative and effective therapies for RA, many patients still have persistently active disease or experience adverse events that can limit use. A growing body of evidence suggests that Treg modulation could offer a new therapeutic strategy in RA and other autoimmune disorders. Here, we describe tregalizumab (BT-061), which is a novel, non-depleting IgG1 mAb that binds to a unique epitope of CD4. Tregalizumab represents the first humanized anti-CD4 mAb that selectively induces Treg activation.

Keywords: monoclonal antibody, regulatory T cells, CD4 T cells, autoimmunity, rheumatoid arthritis

\section{INTRODUCTION}

Regulatory T cells (Tregs) are an essential part of the immune system ensuring the maintenance of immunological tolerance and the prevention of autoimmunity (1). They are characterized by the expression of high levels of CD25 (IL2Ra), cytotoxic T lymphocyte-associated antigen 4 (CTLA-4), and glucocorticoid-induced tumor necrosis factor (TNF) receptor family $\alpha$-related protein (GITR). Treg function and homeostasis relies on a stable expression of transcription factor Forkhead Box P3 (FoxP3) (2). Naturally occurring Tregs (nTregs) account for $5-10 \%$ of $C D 4^{+} \mathrm{T}$ lymphocytes in the peripheral blood of healthy subjects (3). In the periphery, Tregs can convert from Foxp3- $\mathrm{T}$ effector cells and are described as induced Tregs (iTregs). Several subpopulations of iTregs have been identified based on phenotypic and functional properties (4).

Functional imbalances of Tregs may contribute to the pathogenesis of rheumatoid arthritis (RA) and other autoimmune diseases (3). This has been described in rodents and is well documented in patients with RA $(5,6)$. Several studies indicate that Treg numbers are increased in the synovial fluid of RA patients, which is likely to be part of the response to inflammation. In RA, the increases of Treg numbers in synovial fluid were similar across diagnoses and disease durations (7). Subsequent studies have typically reported decreased or little change in the proportion of Tregs in the peripheral blood of RA patients compared with healthy controls (8).

Regulatory T cells from the synovial fluid of RA patients express an activated phenotype compared with those in peripheral blood from patients or healthy controls (9). FoxP3 mRNA, CTLA-4, 
OX-40, and GITR levels were also higher in the synovial fluid (9). Coculturing $\mathrm{CD} 4{ }^{+} \mathrm{CD} 25^{-}$cells with irradiated antigen-presenting cells (APCs) and anti-CD3 monoclonal antibodies (mAbs) demonstrated that Tregs from synovial fluid of RA patients were more suppressive than Tregs from peripheral blood (10). Subsequent analyses of Tregs derived from peripheral blood and synovial fluid from RA $(9,11)$ and juvenile idiopathic arthritis (JIA) patients (12) have indicated that Tregs retain their suppressive activity. Indeed, Treg function was markedly attenuated, which was reflected by an impaired ability to suppress T effector cell proliferation in patients with active RA compared with healthy controls (13).

The inflammatory milieu in RA synovium may render $\mathrm{T}$ cells more resistant to modulation by Tregs (14-16). TNF- $\alpha$ has been shown to abrogate the ability of Tregs to suppress $\mathrm{T}$ cell proliferation, although interleukin-6 (IL-6) had no effect (17). However, the effect of TNF- $\alpha$ on Tregs in mice and humans remains an area of discussion and controversy $(18,19)$.

\section{THERAPIES TO INCREASE TREG NUMBERS AND FUNCTION}

The immunomodulatory influence of increased numbers of Tregs on immune responses in disease model systems has been extensively studied and represents an exciting immunotherapeutic strategy (20). Moreover, adoptive transfer of autologous or donor-derived Tregs as a cellular immunotherapy has been successfully studied in initial clinical trials in graft versus host disease (GVHD) $(21,22)$, underlining the therapeutic potential of Tregs. Other therapeutic strategies aimed at manipulating the existing Tregs $(23,24)$. A report on a high-throughput system identified several FDA-approved drugs that increase the number of Tregs with suppressive function (25).

In autoimmune disease, therapies with some approved biologics, including TNF- $\alpha$ inhibitors, have been shown to increase Treg numbers or function (26). For example, treatment with infliximab improved the ability of Tregs to inhibit cytokine production and increased the number of Tregs (27). Likewise, the human anti-TNF- $\alpha$ antibody adalimumab increased the percentage of FoxP $3^{+}$cells with restored regulatory function (28). By contrast, etanercept, a soluble TNF receptor, does not influence Treg cell number and function. It has been shown that TNFR2 expression is required for nTreg-mediated suppression and that TNF- $\alpha$, in addition to stimulating Teff, is able to activate Tregs through TNFR2, which is preferentially expressed by Tregs. Furthermore, TNF- $\alpha$ is required as a critical factor in the activation of Tregs in tissue sites of inflammation (29). Anti-TNF- $\alpha$ therapy in human autoimmune diseases may therefore differentially affect the function of nTregs. Anti-TNF- $\alpha$ therapy is clinically effective in the management of autoimmune diseases (30); however, the mechanisms by which anti-TNF- $\alpha$ therapy exerts a clinical effect are currently not fully understood (29). The IL-6 inhibitor tocilizumab has been shown to be effective for the treatment of RA (31). Inhibition of IL-6 by tocilizumab can increase the number of Tregs, thereby restoring the Th17:Treg cell ratio in responding patients. Some approved biologics for the treatment of autoimmune disease therefore influence Treg numbers and function, contributing to their effectiveness.

\section{BIOLOGICS TARGETING THE T CELL RESPONSE}

Current biologic RA therapies mainly target cytokines, including TNF- $\alpha$ (32), IL-1 $(33,34)$, and IL-6 (35). Recently, based on the apparent imbalance between Th17 and Treg activity (36), targeting IL-17 has been identified as another potential treatment intervention $(32,37)$, and anti IL-17 mAbs have been studied in RA but are not yet clinically available $(38,39)$.

Abatacept is a fusion protein of the CTLA-4 receptor and Fc domain of IgG1, which abrogates T cell costimulation, and thereby modulates $\mathrm{T}$ cell responses and interactions between $\mathrm{T}$ and $\mathrm{B}$ cells. It was approved in 2006 for the treatment of established (40-43) and early RA (44) and provides clinical "proof-of-concept" that targeting $\mathrm{T}$ cells is a rational treatment approach. The T cell receptor (TCR) interacts with CD3 to process signals resulting from an interaction with an antigen (38). Therefore, anti-CD3 therapy may be beneficial as an immunosuppressive agent. In mouse models of arthritis, anti-CD3 mAbs also reduce disease activity by induction of Tregs, leading to increased $\mathrm{CD}^{+}$and $\mathrm{CD}^{+}$ Treg cells (45), and a transient downregulation of the TCR (46). Furthermore, anti-CD3 mAb therapy has induced remission in type I diabetes mellitus in non-obese diabetic (NOD) mice (47).

The clinical use of anti-CD3 mAbs has been limited by the induction of inflammatory cytokines and mitogenicity. Recent products have been developed to negate $F c$ receptor (FCR) functions, including complement-dependent cytotoxicity (CDC) and antibody-dependent cell-mediated cytotoxicity (ADCC). Teplizumab, an IgG1 anti-CD3 $\mathrm{mAb}$ with reduced FcR binding (48), has been assessed in type 1 diabetes and psoriatic arthritis. Treatment with teplizumab resulted in reduced C-peptide responses and a reduction in HbA1C levels in patients (49), but a further trial was halted due to an increased risk of adverse events, including lymphopenia. The Phase III PROTÉGÉ trial of teplizumab in type 1 diabetes failed to meet the primary end point, although there was evidence of benefit in certain subgroups (50). A dose-finding study using otelixizumab, a humanized CD3 mAb in type 1 diabetes, demonstrated reduced insulin requirements (51). However, a Phase III trial in type 1 diabetes (48) reported no significant benefit. Otelixizumab was also assessed in RA but development appears to be discontinued $(52,53)$.

These data indicate that anti-CD3 mAb treatment might be a feasible therapeutic approach; however, limited understanding of the potential mode of action of these mAbs in humans hinders interpretation of the studies to date (54).

The TCR coreceptor CD4 seems to be an attractive target for the modulation of $\mathrm{T}$ cell function. CD4 is widely expressed on $\mathrm{T}$ cells; therefore, anti-CD4 therapy might affect multiple subtypes, including potentially beneficial Tregs $(55,56)$. Current anti-CD4 $\mathrm{mAbs}$ act by coating the target CD4 molecule, making it inaccessible for ligands, downmodulating CD4, or depleting $\mathrm{CD} 4{ }^{+}$target cells via induction of CDC or ADCC.

In mouse models of inflammatory arthritis, the anti-CD4 mAb YTS177 prevented or delayed onset of inflammatory disease (57), while in a rat kidney transplant model, the non-depleting mouse anti-rat CD4 mAb RIB5/2-induced long-term survival of the transplants. RIB5/2-induced tolerance was stable despite 
persistence of alloreactive $\mathrm{T}$ cells, suggesting a role of active tolerance-maintaining mechanisms. RIB 5/2-mediated tolerance can be adoptively transferred by Tregs isolated from the graft (58). The chimeric anti-CD4 mAb, priliximab (cM-T412) was not effective in RA patients, despite depleting peripheral CD4 ${ }^{+} \mathrm{T}$ cells at higher doses (59). However, a humanized non-depleting antiCD4 mAb (OKTcdr4a) decreased CRP and resulted in transient clinical improvements in RA (60).

Keliximab, a primatized anti-CD4 mAb, demonstrated activity in RA patients in two randomized controlled trials and clinical responses correlated with CD4 T cell coating by keliximab (61). This suggests that non-depleting anti-CD4 mAbs could have therapeutic utility in RA. Clenoliximab, an IgG4 derivative of keliximab, modified to further reduce Fc-binding activity, demonstrated a reduced ability to downmodulate the CD4 receptor in vitro, but retained activity in vivo through dose-dependent CD4 "stripping" from the cell surface $(62,63)$. In a Phase II trial, clenoliximab induced American College of Rheumatology (ACR) criteria responses without CD4 depletion; however, this was not confirmed with long-term dosing (64). Another anti-CD4 mAb (4162W94) considered to be non-depleting resulted in sustained downmodulation of CD4 lymphocytes in an open-label pilot study (65). Although a placebo-controlled, repeat-cycle, followup trial demonstrated significant clinical activity in RA, unacceptable CD4 lymphopenia, and skin rashes lead to discontinuation of therapy (66).

Anti-CD4 antibodies with different pharmacodynamic (PD) properties have been investigated and shown to modulate $\mathrm{T}$ cell function in model systems and in clinical trials. However, treatment in clinical trials with the anti-CD4 mAbs investigated to date did not result in long-lasting clinical benefits.

\section{TREGALIZUMAB}

Tregalizumab represents a novel, humanized, anti-human CD4 IgG1 mAb, which binds to a unique epitope of CD4 in the IgGlike C2 type 1 domain (also known as D2) on the opposite side of the binding region for other known ligands, including other anti-CD4 mAbs, gp120, and MHC class II. This allows concurrent binding of a class II MHC molecule or a gp120 HIV-1 envelope protein (67). Tregalizumab is derived from a murine predecessor B-F5 by complementarity-determining region (CDR) grafting and subcloning.

Several effector functions of tregalizumab have been analyzed in vitro. Tregalizumab is unable to mediate induction of CDC, ADCC, or apoptosis in target cells (68). However, in contrast to other CD4 antibodies, the precursor antibody B-F5 and tregalizumab were both found to selectively activate Tregs $(67,69)$.

Regulatory $\mathrm{T}$ cells remain in an inactivated state and do not exhibit suppressive properties unless activated by appropriate signals via their TCR (70). In vitro incubation of Tregs with antiCD3 antibodies is considered as an optimal stimulus to induce their suppressive activity, although anti-CD3 antibodies have no selectivity for Tregs and activate conventional $\mathrm{T}$ cells as well as Tregs.

Using in vitro assays, it could be demonstrated that, in contrast to the other CD4 antibodies analyzed, tregalizumab can provide an activation signal selectively to Tregs $(67,69)$. Tregalizumabtreated Tregs strongly suppressed proliferation of CD4 and CD8 effector T cells following allogeneic or antigen-specific activation in mixed lymphocyte reactions (Figures 1A,B).

Cyclic AMP (cAMP) has been shown to be elevated in activated Tregs, which is then transmitted via gap junctions directly
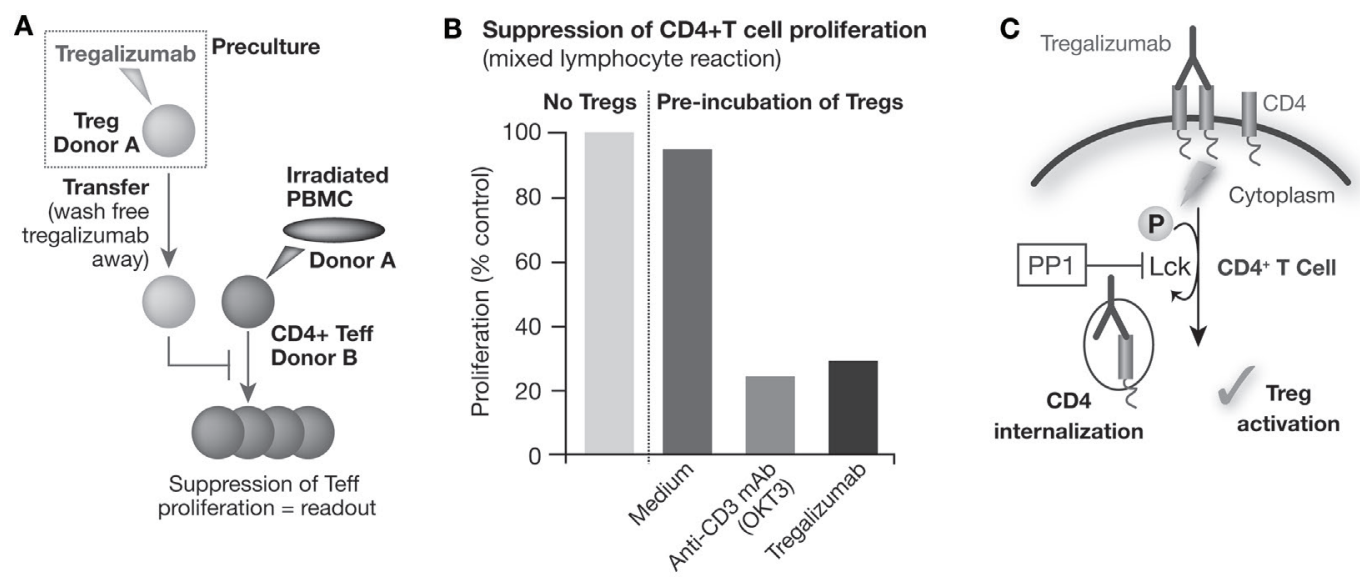

FIGURE 1 | Tregalizumab is able to activate the suppressive capacity of regulatory T cells. (A) Tregs were isolated and pre-incubated with plate-bound tregalizumab, OKT-3 mAb, or medium and transferred to a mixed lymphocyte reaction using allogeneic, CD3-depleted, irradiated PBMCs to activate the proliferation of Teffs. (B) The proliferation of allogenic stimulated Teffs with tregalizumab pretreated Tregs is shown compared with the proliferation without Tregs. (C) Tregalizumab engages the TCR signaling pathway. Incubation of Tregs with tregalizumab evokes signaling events in Tregs that mimic a signal through the T cell receptor complex without the need for direct CD3 or TCR stimulation. T cell receptor complex signaling represents a crucial event in the activation of Tregs since blockade of the corresponding signaling pathway resulted in the loss of suppressive activity of Tregs. Tregalizumab delivers a comparable signal as usually conferred by TCR binding in Tregs, resulting in activation/phosphorylation of the T cell receptor downstream signaling molecule ZAP-70 ( $\zeta$-chain-associated protein). This event leads to signals that finally trigger internalization of the tregalizumab-CD4 complex. As a consequence, CD4 expression levels on CD4+ T cells are downmodulated by tregalizumab in the physiological setting. This downmodulation causes a transient decrease of CD4 molecules on the cell surface, which is followed by a recovery of expression levels over time $(67,69)$. 
into responder T cells. The suppressive activity of nTregs can be abolished by cAMP antagonists as well as by gap junction inhibitors, which block the cell contact-dependent transfer of cAMP to responder T cells (71). In vitro, tregalizumab is able to activate Tregs as demonstrated by increased intracellular cAMP and $\mathrm{Ca}^{2+}$ levels, and by increased secretion of transforming growth factor beta (TGF- $\beta$ ) (67).

Tregalizumab recognizes the human CD4 molecule not only on Tregs but also on conventional T cells. Despite this, binding does not impair the proliferative capacity of these cells per se. In contrast to other anti-CD4 antibodies, tregalizumab does not inhibit the proliferation elicited by anti-CD3/anti-CD28 stimulation. Importantly, tregalizumab does not lead to the activation and proliferation of conventional $\mathrm{T}$ cells and does not induce the secretion of proinflammatory cytokines, in contrast to anti-CD3 mAbs. Indeed, tregalizumab reduced proliferation and cytokine secretion when isolated peripheral blood mononuclear cells (PBMCs) were stimulated with tetanus toxoid in a dosedependent manner (68).

Incubation of Tregs with tregalizumab evokes signaling events in Tregs that mimic a signal through the TCR complex, without the need for direct CD3 or TCR stimulation $(67,69)$. TCR complex signaling represents a crucial event in the activation of Tregs since blockade of the corresponding signaling pathway, for example, via PP1, a specific src family kinase inhibitor, resulted in the loss of suppressive activity of Tregs (Figure 1C). Therefore, tregalizumab binding to CD4 triggers the induction of the signaling cascade in Tregs with the activation/phosphorylation of the TCR downstream signaling molecule ZAP-70 ( $\zeta$-chainassociated protein). In vitro studies have shown that several signaling molecules of the TCR pathway are engaged and become phosphorylated (67). When comparing commercially available anti-CD4 antibodies to tregalizumab, significant differences in signaling strength were observed. Although the phosphorylation signal on Lck was weakest with tregalizumab, it also mediated phosphorylation of LAT, SLP-76, PLC- $\gamma$, and MEK. However, tregalizumab did not induce phosphorylation of Itk, ERK, PKC, MAPK, or NF- $\kappa B$, unlike anti-CD3 treatment or the other antiCD4 antibodies tested (67). Therefore, only tregalizumab was able to induce suppressive properties of Tregs. Interestingly, to date, no signaling molecule has been found that was specifically activated in Tregs in comparison to $\mathrm{CD} 4^{+} \mathrm{T}$ effector cells, and both Tregs and $\mathrm{T}$ effector cells responded to tregalizumab with similar phosphorylation events.

Other antibodies targeting cell surface receptors trigger the internalization of the antibody-receptor complex, resulting in decreased receptor surface expression over time (72). The decrease of CD4 surface receptor expression mediated by tregalizumab is detectable in vitro after cross-linking using a secondary antibody. Neither isotype control antibodies nor the Fab fragment of tregalizumab were able to mediate CD4 downmodulation. In vitro, the maximal CD4 decrease was detected within a few hours and the magnitude of CD4 downmodulation seemed to be dose dependent, followed by a recovery over time. Interestingly, CD4 downmodulation occurs in both Treg and effector T cells without any observed differences in kinetics. CD4 downmodulation depends on tregalizumab-induced CD4 receptor signaling, which is triggered by the binding of tregalizumab to surface CD4. This specific signaling pathway is directly linked to the internalization event. PBMCs treated with tregalizumab in combination with the Lck-specific inhibitor PP1 led to a strong inhibition of CD4 receptor downmodulation. This indicates that the internalization of CD4 by tregalizumab depends on functional CD4 signaling and establishes a direct link between the activation of Tregs with CD4 downmodulation.

Downmodulation of CD4 expression levels has been reported in patients treated with tregalizumab (73), and this effect is of relevance as a marker for monitoring the activity of tregalizumab in vivo. Therefore, we hypothesized that the downmodulation of CD4 on the T cell surface could serve as a marker of tregalizumab PDs in vivo. This strategy was applied to establish a dose-response model of the CD4 modulation (73).

\section{TREGALIZUMAB CLINICAL DEVELOPMENT}

The clinical development program of tregalizumab encompassed eight clinical studies: two in healthy subjects, two in psoriasis patients, and four in RA patients. Initial clinical data from Phase IIa dose-finding trials of tregalizumab in psoriasis (74) and RA (75) showed promising clinical effects. In a study of 55 patients with psoriasis who had failed to respond to systemic treatment, a single subcutaneous (SC) dose of tregalizumab (between 25 and $100 \mathrm{mg}$ ) induced psoriasis area and severity index (PASI) 50 responses in 19 patients, including 2 with PASI 75 as best observed responses. There was no evidence of increased cytokine levels or depletion of $\mathrm{CD}^{+} \mathrm{T}$ cells, and no increased risk of infections (74). Similarly, in a dose-finding study in patients with active RA who were disease-modifying antirheumatic drugs (DMARD) incomplete responders, tregalizumab monotherapy rapidly improved tender and swollen joint counts (75). At week 7 , after 6 weeks of treatment, a maximum response of ACR 20/50/70 in the $50 \mathrm{mg}$ SC dosing arm was achieved in 67,33 , and $17 \%$ of patients, respectively, compared to 14,7 , and $0 \%$ in the placebo arm. In some patients, improvements persisted beyond the dosing period.

A large Phase IIb study with 321 patients with RA (TREAT 2b, T cell REgulating Arthritis Trial 2b) was initiated. TREAT $2 b$ was a double-blind, randomized, placebo-controlled, Phase IIb trial with four treatment groups to evaluate the efficacy and safety of tregalizumab in methotrexate-inadequate responders. In the active dosing groups, tregalizumab was administered at SC doses of 25,100 , and $200 \mathrm{mg}$ once weekly over 24 weeks in combination with methotrexate. Patients in the control arm received methotrexate only. In patients who responded to treatment, therapy was extended for a further 6 months (76). At week 12, none of the three dosing arms of tregalizumab showed a statistically significant improvement in ACR20 score (primary endpoint) when compared to placebo. Tregalizumab was generally well tolerated with usually mild-to-moderate adverse events balanced between placebo and treatment arms. Neither tuberculosis, opportunistic infections, major adverse cardiovascular events nor malignancies were reported during the study. No difference in infections between tregalizumab and placebo was observed. The results of tregalizumab in RA reported in the TREAT2b trial do not 

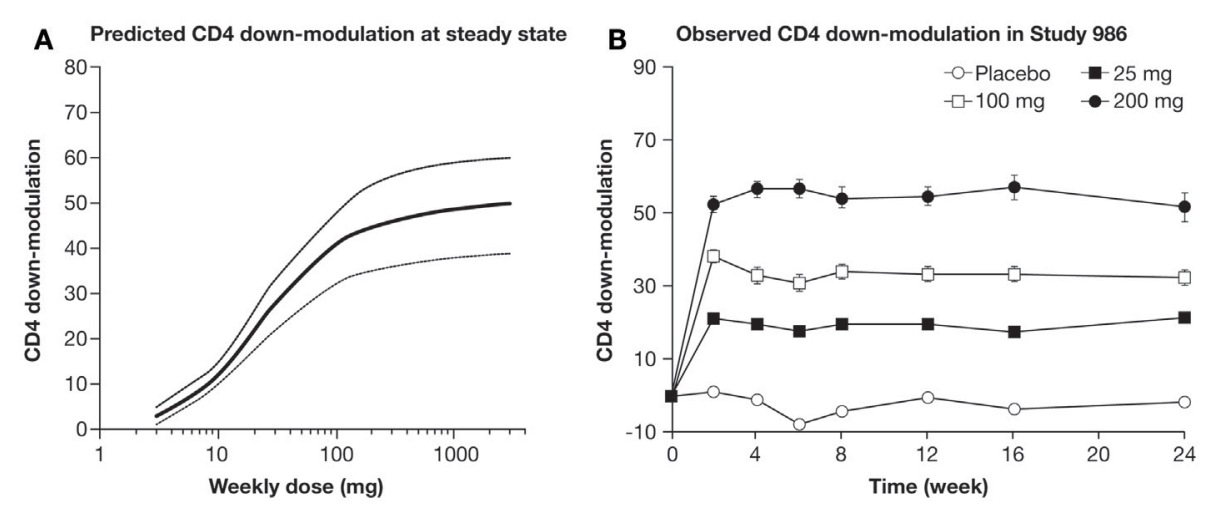

FIGURE 2 | (A) PK/PD model was established to predict time course of CD4 downmodulation (\% of baseline) after weekly dosing. (B) Mean CD4 downmodulation on CD4 T cells per dose group. CD4 modulation ( \pm SEM) was measured by FACS analysis at weeks 0, 2, 4, 6, 8, 12, 16, and 24 just prior to the next dosing (77).

currently justify further clinical development in this indication due to lack of a responder population demonstrating sufficient efficacy. Nevertheless, the PD effects, including modulation of CD4 receptor expression that were observed in tregalizumabtreated patients, were as expected and consistent with predictions of established pharmacokinetic (PK)/PD modeling (73) (Figures 2A,B).

In summary, anti-CD4 antibodies demonstrate different PD properties and several mechanisms have been investigated in clinical trials to influence $\mathrm{T}$ cell-driven diseases. In these studies, treatment with anti-CD4 mAbs did not result in significant clinical benefit. Tregalizumab represents a mAb with a novel and unique mode of action and signs of efficacy have been observed in Phase II trials in psoriasis and RA. However, statistically significant efficacy could not be confirmed in the larger trial in patients with RA. Antibody activity was demonstrated in all trials by measuring CD4 modulation as a PD marker and a PK/PD model system was also established to predict the dose-response of CD4 modulation. In parallel, the safety profile observed in earlier studies has been confirmed in the larger trial. More mechanistic and clinical data are needed to better understand applicability of this novel therapeutic approach; however, the unique mechanism of tregalizumab remains attractive and should be explored in further diseases

\section{REFERENCES}

1. Sakaguchi S, Sakaguchi N, Asano M, Itoh M, Toda M. Immunologic self-tolerance maintained by activated $\mathrm{T}$ cells expressing IL-2 receptor alpha-chains (CD25). Breakdown of a single mechanism of self-tolerance causes various autoimmune diseases. J Immunol (1995) 155:1151-64.

2. Jiang S. Regulatory $\mathrm{T}$ cells: from bench to bedside. Int Immunopharmacol (2009) 9(5):515-7. doi:10.1016/j.intimp.2008.01.038

3. Notley C, Ehrenstein M. The yin and yang of regulatory $\mathrm{T}$ cells and inflammation in RA. Nat Rev Rheumatol (2010) 6(10):572-7. doi:10.1038/ nrrheum.2010.143

4. Bluestone JA, Abbas AK. Natural versus adaptive regulatory T cells. Nat Rev Immunol (2003) 3(3):253-7. doi:10.1038/nri1032

5. Sakaguchi S. Regulatory T cells: history and perspective. Methods Mol Biol (2011) 707:3-17. doi:10.1007/978-1-61737-979-6_1 in which insufficient Treg activity is postulated as a pathophysiological mechanism.

\section{AUTHOR CONTRIBUTIONS}

MK: wrote the manuscript, designed the work, analyzed and interpreted the data, and approved the manuscript. FR, SA, and $\mathrm{BD}$ : designed the work, analyzed and interpreted the data, revised and approved the manuscript. BD was accountable for all aspects of the work. JS analyzed and interpreted the data, revised and approved the manuscript, and was accountable for all aspects of the work.

\section{ACKNOWLEDGMENTS}

We thank Ian Morgan, Sarah Diffen, and Kalpesh Patel, from 4C Consultants International for editing and proofreading of the manuscript.

\section{FUNDING}

This work was funded by Biotest AG. AbbVie provided financial support to Biotest AG for scientific and clinical evaluation of BT-061.

6. Sakaguchi S. Naturally arising FOXP3-expressing $\mathrm{CD} 25^{+} \mathrm{CD} 4^{+}$regulatory $\mathrm{T}$ cells in immunological tolerance to self and non-self. Nat Immunol (2005) 6(4):345-52. doi:10.1038/ni1178

7. Cao D, van Vollenhoven R, Klareskog L, Trollmo C, Malmström V. $\mathrm{CD} 25$ brightCD4 ${ }^{+}$regulatory $\mathrm{T}$ cells are enriched in inflamed joints of patients with chronic rheumatic disease. Arthritis Res Ther (2004) 6(4):R335-46. doi: $10.1186 /$ ar1192

8. Miyara M, Gorochov G, Ehrenstein M, Musset L, Sakaguchi S, Amoura Z. Human FoxP3+ regulatory $\mathrm{T}$ cells in systemic autoimmune diseases. Autoimmun Rev (2011) 10(12):744-55. doi:10.1016/j.autrev.2011.05.004

9. Möttönen M, Heikkinen J, Mustonen L, Isomäki P, Luukkainen R, Lassila O. $\mathrm{CD}^{+} \mathrm{CD}^{2} 5^{+} \mathrm{T}$ cells with the phenotypic and functional characteristics of regulatory $\mathrm{T}$ cells are enriched in the synovial fluid of patients with rheumatoid arthritis. Clin Exp Immunol (2005) 140(2):360-7. doi:10.1111/j.1365-2249.2005.02754.x 
10. Van Amelsfort JM, Jacobs KM, Bijlsma JW, Lafeber FP, Taams LS. CD $4^{+} \mathrm{CD} 25^{+}$ regulatory $\mathrm{T}$ cells in rheumatoid arthritis: differences in the presence, phenotype and function between peripheral blood and synovial fluid. Arthritis Rheum (2004) 50(9):2775-85. doi:10.1002/art.20499

11. Lawson CA, Brown AK, Beajarano V, Douglas SH, Burgoyne CH, Greenstein AS, et al. Early rheumatoid arthritis is associated with a deficit in the $\mathrm{CD} 4{ }^{+} \mathrm{CD} 25$ high regulatory T cell population in peripheral blood. Rheumatology (2006) 45(10):1210-7. doi:10.1093/rheumatology/kel089

12. Ruprecht CR, Gattorno M, Ferlito F, Gregorio A, Martini A, Lanzavecchia $\mathrm{A}$, et al. Coexpression of $\mathrm{CD} 25$ and $\mathrm{CD} 27$ identifies $\mathrm{FOXP}^{+}$regulatory $\mathrm{T}$ cells in inflamed synovia. J Exp Med (2005) 201(11):1793-803. doi:10.1084/ jem.20050085

13. Valencia X, Stephens G, Goldbach-Mansky R, Wilson M, Shevach EM, Lipsky $\mathrm{PE}$. TNF downmodulates the function of human $\mathrm{CD} 4{ }^{+} \mathrm{CD} 25$ hi T-regulatory cells. Blood (2006) 108(1):253-61. doi:10.1182/blood-2005-11-4567

14. Pasare C, Medzhitov R. Toll pathway-dependant blockade of $\mathrm{CD} 4{ }^{+} \mathrm{CD} 25^{+} \mathrm{T}$ cell-mediated suppression by dendritic cells. Science (2003) 299(5609):1033-6. doi:10.1126/science.1078231

15. Nelson BH. IL-2, regulatory $\mathrm{T}$ cells and tolerance. J Immunol (2004) 172(7):3983-8. doi:10.4049/jimmunol.172.7.3983

16. Bayry J, Sibéril S, Triebel F, Tough DF, Kaveri SV. Rescuing $\mathrm{CD} 4{ }^{+} \mathrm{CD} 25^{+}$ regulatory T-cell functions in rheumatoid arthritis by cytokine-targeted monoclonal antibody therapy. Drug Discov Today (2007) 12(13-14):548-52. doi:10.1016/j.drudis.2007.05.002

17. Van Amelsfort JM, van Roon JA, Noordegraaf M, Jacobs KM, Bijlsma JW, Lafeber FP, et al. Proinflammatory mediator-induced reversal of $\mathrm{CD} 4^{+} \mathrm{CD} 25^{+}$ regulatory T cell-mediated suppression in rheumatoid arthritis. Arthritis Rheum (2007) 56(3):732-42. doi:10.1002/art.22414

18. Chen X, Bäumel M, Männel DN, Howard OM, Oppenheim JJ. Interaction of TNF with TNF receptor type 2 promotes expansion and function of mouse $\mathrm{CD} 4{ }^{+} \mathrm{CD} 25^{+}$T regulatory cells. J Immunol (2007) 179(1):154-61. doi:10.4049/ jimmunol.179.1.154

19. Nagar M, Jacob-Hirsch J, Vernitsky H, Berkun Y, Ben-Horin S, Amariglio $\mathrm{N}$, et al. TNF activates a NF-kappaB-regulated cellular program in human CD45RA- regulatory $\mathrm{T}$ cells that modulates their suppressive function. Immunol (2010) 184(7):3570-81. doi:10.4049/jimmunol.0902070

20. June CH, Blazar BR. Clinical application of expanded $\mathrm{CD} 4^{+} 25^{+}$cells. Semin Immunol (2006) 18(2):78-88. doi:10.1016/j.smim.2006.01.006

21. Brunstein CG, Miller JS, Cao Q, McKenna DH, Hippen KL, Curtsinger J, et al. Infusion of ex vivo expanded $\mathrm{T}$ regulatory cells in adults transplanted with umbilical cord blood: safety profile and detection kinetics. Blood (2011) 117(3):1061-70. doi:10.1182/blood-2010-07-293795

22. Di Ianni M, Falzetti F, Carotti A, Terenzi A, Castellino F, Bonifacio E, et al. Tregs prevent GVHD and promote immune reconstitution in HLAhaploidentical transplantation. Blood (2011) 117(14):3921-8. doi:10.1182/ blood-2010-10-311894

23. von Boehmer H, Daniel C. Therapeutic opportunities for manipulating $\mathrm{T}(\mathrm{reg})$ cells in autoimmunity and cancer. Nat Rev Drug Discov (2013) 12(1):51-63. doi:10.1038/nrd3683

24. Pere H, Tanchot C, Bayry J, Terme M, Taieb J, Badoual C, et al. Comprehensive analysis of current approaches to inhibit regulatory $\mathrm{T}$ cells in cancer. Oncoimmunology (2012) 1(3):326-33. doi:10.4161/onci.18852

25. Mao R, Xiao W, Liu H, Chen B, Yi B, Kraj P, et al. Systematic evaluation of 640 FDA drugs for their effect on $\mathrm{CD}^{+}{ }^{+} \mathrm{Foxp}^{+}{ }^{+}$regulatory $\mathrm{T}$ cells using a novel cell-based high throughput screening assay. Biochem Pharmacol (2013) 85(10):1513-24. doi:10.1016/j.bcp.2013.03.013

26. Byng-Maddick R, Ehrenstein MR. The impact of biological therapy on regulatory $\mathrm{T}$ cells in rheumatoid arthritis. Rheumatology (Oxford) (2015) 54(5):768-75. doi:10.1093/rheumatology/keu487

27. Ehrenstein MR, Evans JG, Singh A, Moore S, Warnes G, Isenberg DA, et al. Compromised function of regulatory $\mathrm{T}$ cells in rheumatoid arthritis and reversal by anti-TNF-alpha therapy. J Exp Med (2004) 200(3):277-85. doi:10.1084/jem.20040165

28. McGovern JL, Nguyen DX, Notley CA, Mauri C, Isenberg DA, Ehrenstein MR. Th17 cells are restrained by Treg cells via the inhibition of interleukin- 6 in patients with rheumatoid arthritis responding to anti-tumor necrosis factor antibody therapy. Arthritis Rheum (2012) 64(10):3129-38. doi:10.1002/ $\operatorname{art} .34565$
29. Housley WJ, Adams CO, Nichols FC, Puddington L, Lingenheld EG, Zhu L, et al. Natural but not inducible regulatory $\mathrm{T}$ cells require TNF-alpha signaling for in vivo function. J Immunol (2011) 186(12):6779-87. doi:10.4049/ jimmunol.1003868

30. Sfikakis PP. The first decade of biologic TNF antagonists in clinical practice: lessons learned, unresolved issues and future directions. Curr Dir Autoimmun (2010) 11:180-210. doi:10.1159/000289205

31. Takeuchi T, Tanaka Y, Amano K, Hoshi D, Nawata M, Nagasawa H, et al. Clinical, radiographic and functional effectiveness of tocilizumab for rheumatoid arthritis patients-REACTION 52-week study. Rheumatology (2011) 50(10):1908-15. doi:10.1093/rheumatology/ker221

32. Taylor PC, Feldmann M. Anti-TNF biologic agents: still the therapy of choice for rheumatoid arthritis. Nat Rev Rheumatol (2009) 5(10):578-82. doi:10.1038/nrrheum.2009.181

33. Cohen S, Hurd E, Cush J, Schiff M, Weinblatt ME, Moreland LW, et al. Treatment of rheumatoid arthritis with anakinra, a recombinant human interleukin-1 receptor antagonist, in combination with methotrexate: results of a twenty-four-week, multicenter, randomized, double-blind, placebo-controlled trial. Arthritis Rheum (2002) 46(3):614-24. doi:10.1002/art.10141

34. Fleishmann R. Anakinra in the treatment of rheumatic disease. Expert Rev Clin Immunol (2006) 2(3):331-40. doi:10.1586/1744666X.2.3.331

35. Assier E, Boissier MC, Dayer JM. Interleukin-6: from identification of the cytokine to development of targeted treatments. Joint Bone Spine (2010) 77(6):532-6. doi:10.1016/j.jbspin.2010.07.007

36. Boisser MC, Assier E, Falgarone G, Bessis N. Shifting the imbalance from Th1/Th2 to Th17/treg: the changing rheumatoid arthritis paradigm. Joint Bone Spine (2008) 75(4):373-5. doi:10.1016/j.jbspin.2008.04.005

37. Heuber AJ, Asquith DL, Miller AM, Reilly J, Kerr S, Leipe J, et al. Mast cells express IL-17A in rheumatoid arthritis synovium. JImmunol (2010) 184(7):3336-40. doi:10.4049/jimmunol.0903566

38. Genovese M, Van den Bosch F, Roberson SA, Bojin S, Biagini IM, Ryan P, et al. LY2439821, a humanized anti-IL-17 monoclonal antibody, in the treatment of patients with rheumatoid arthritis: a Phase 1 randomized double-blind, placebo-controlled, proof-of-concept study. Arthritis Rheum (2010) 62(4):929-39. doi:10.1002/art.27334

39. Kuhns MS, Davis MM, Garcia KC. Deconstructing the form and function of the TCR/CD3 complex. Immunity (2006) 24(2):133-9. doi:10.1016/j. immuni.2006.01.006

40. Genovese M, Durez P, Richards H, Hugot S, Thangavelu K, Mpofu S. Secukinumab (AIN457), a novel monoclonal antibody targeting IL-17A demonstrates efficacy in active rheumatoid arthritis patients despite stable methotrexate treatment: results of a Phase IIb study. Arthritis Rheum (2011) 63(Suppl 10):401.

41. Genovese MC, Becker JC, Schiff M, Luggen M, Sherrer Y, Kremer J, et al. Abatacept for rheumatoid arthritis refractory to tumor necrosis factor alpha inhibition. NEngl J Med (2005) 353(11):1114-23. doi:10.1056/NEJMoa050524

42. Genovese MC, Covarrubias A, Leon G, Mysler E, Keiserman M, Valente $\mathrm{R}$, et al. Subcutaneous abatacept versus intravenous abatacept: a Phase IIIb noninferiority study in patients with an inadequate response to methotrexate. Arthritis Rheum (2011) 63(10):2854-64. doi:10.1002/art.30463

43. Kremer JM, Dougados M, Emery P, Durez P, Sibilia J, Shergy W, et al. Treatment of rheumatoid arthritis with the selective costimulation modulator abatercept: twelve-month results of a Phase IIb, double-blind, randomized, placebo-controlled trial. Arthritis Rheum (2005) 52(8):2263-71. doi:10.1002/ art. 21201

44. Leffers HC, Ostergaard M, Glintborg B, Krogh NS, Foged H, Tarp U, et al. Efficacy of abatacept and tocilizumab in patients with rheumatoid arthritis treated in clinical practice: results from the nationwide Danish DANBIO registry. Ann Rheum Dis (2011) 70(7):1216-22. doi:10.1136/ $\operatorname{ard} .2010 .140129$

45. Notley CA, McCann FE, Inglis JJ, Williams RO. Anti-CD3 therapy expands the numbers of $\mathrm{CD}^{+}$and $\mathrm{CD}^{+}$Treg cells and induces sustained amelioration of collagen-induced arthritis. Arthritis Rheum (2009) 62(1):171-8. doi:10.1002/ art. 25058

46. Chatenoud L, Baudrihaye MF, Kreis H, Goldstein G, Schindler J, Bach JF. Human in vivo antigenic modulation induced by the anti-T cell OKT3 monoclonal antibody. Eur J Immunol (1982) 12(11):979-82. doi:10.1002/ eji.1830121116 
47. Chatenoud L, Thervet E, Primo J, Bach JF. Anti-CD3 antibody induces longterm remission of overt autoimmunity in nonobese diabetic mice. Proc Natl Acad Sci U S A (1994) 91(1):123-7. doi:10.1073/pnas.91.1.123

48. Reichert JM. Antibody-based therapeutics to watch in 2011. MAbs (2011) 3(1):76-99. doi:10.4161/mabs.3.1.13895

49. Herold KC, Hagopian W, Auger JA, Poumian-Ruiz E, Taylor L, Donaldson D, et al. Anti-CD3 monoclonal antibody in new-onset type 1 diabetes mellitus. $N$ Engl J Med (2002) 346(22):1692-8. doi:10.1056/NEJMoa012864

50. Sherry N, Hagopian W, Ludvigsson J, Jain SM, Wahlen J, Ferry RJ Jr, et al. Teplizumab for treatment of type 1 diabetes (Protégé study): 1-year results from a randomised, placebo-controlled trial. Lancet (2011) 378(9790):487-97. doi:10.1016/S0140-6736(11)60931-8

51. Keymeulen B, Walter M, Mathieu C, Kaufman L, Gorus F, Hilbrands R, et al. Four-year metabolic outcome of a randomised controlled CD3-antibody trial in recent-onset type 1 diabetic patients depends on their age and baseline residual beta cell mass. Diabetologia (2010) 53(4):614-23. doi:10.1007/ s00125-009-1644-9

52. ClinicalTrials.gov. Safety, Pharmacodynamics and Pharmacokinetics of GSK2136525 Repeat Dose in Rheumatoid Arthritis (2015). Available from: www.clinicaltrials.gov/show/nct01077531

53. ClinicalTrials.gov. Repeat Dose Subcutaneous Rheumatoid Arthritis Efficacy Study (2015). Available from: www.clinicaltrials.gov/show/nct01101555

54. Bresson D, von Herrath M. Humanizing animal models: a key to autoimmune diabetes treatment. Sci Transl Med (2011) 3(68):68s4. doi:10.1126/ scitranslmed.3002102

55. Piccirillo CA, Shevack EM. Naturally occurring CD $4^{+} \mathrm{CD} 25^{+}$immunoregulatory T cells: central players in the arena of peripheral tolerance. Semin Immunol (2004) 16(2):81-8. doi:10.1016/j.smim.2003.12.003

56. Strand V, Kimberly R, Isaacs JD. Biologic therapies in rheumatology: lessons learned, future directions. Nat Rev Drug Discov (2007) 6(1):75-92. doi: $10.1038 / \mathrm{nrd} 2196$

57. Duarte J, Agua-Doce A, Oliveira VG, Fonseca JE, Graca L. Modulation of IL-17 and Foxp3 expression in the prevention of autoimmune arthritis in mice. PLoS One (2010) 5(5):e10558. doi:10.1371/journal.pone.0010558

58. Pascher A, Proesch S, Pratschke J, Reutzel-Selke A, Sawitzki B, Lehmann M, et al. Rat cytomegalovirus infection interferes with anti-CD4 mAb-(RIB 5/2) mediated tolerance and induces chronic allograft damage. Am J Transplant (2006) 6(9):2035-45. doi:10.1111/j.1600-6143.2006.01453.x

59. Moreland LW, Pratt PW, Mayes MD, Postlethwaite A, Weisman MH, Schnitzer $\mathrm{T}$, et al. Double-blind, placebo-controlled multicenter trial using chimeric monoclonal anti-CD4 antibody, cM-T412, in rheumatoid arthritis patients receiving concomitant methotrexate. Arthritis Rheum (1995) 38(11):1581-8. doi:10.1002/art.1780381109

60. Schulze-Koops H, Davis L, Haverty P, Wacholtz MC, Lipsky PE. Reduction of Th1 cell activity in peripheral circulation of patients with rheumatoid arthritis after treatment with a non-depleting humanized monocolonal antibody to CD4. J Rheumatol (1998) 25(11):2065-76.

61. Mason U, Aldrich J, Breedveld F, Davis CB, Elliott M, Jackson M, et al. CD4 coating, but not CD4 depletion, is a predictor of efficacy with primatized monoclonal anti-CD4 treatment of active rheumatoid arthritis. J Rheumatol (2002) 29(2):220-9.

62. Reddy MP, Kinney CAS, Chaikin MA, Payne A, Fishman-Lobell J, Tsui P, et al. Elimination of Fc receptor-dependent effector functions of a modified IgG4 monoclonal antibody to human CD4. J Immunol (2000) 164(4):1925-33. doi:10.4049/jimmunol.164.4.1925

63. Hepburn TW, Totoritis MC, Davis CB. Antibody-mediated stripping of CD4 from lymphocyte cell surface in patients with rheumatoid arthritis. Rheumatology (2003) 42(1):54-61. doi:10.1093/rheumatology/keg030

64. Luggen ME, Schechtman J, Kivitz A, Greenwald M, Forstot J, Boling E, et al. Results of a Phase II, double-blind, randomized study of a nondepleting anti-CD4 monoclonal antibody (clenoliximab) given in combination with methotrexate $(\mathrm{mtx})$ in patients with moderate to severe rheumatoid arthritis (RA). Ann Rheum Dis (2003) 62(Suppl 2):O0004.

65. Choy EH, Connolly DJ, Rapson N, Jeal S, Brown JC, Kingsley GH, et al. Pharmacokinetic, pharmacodynamic and clinical effects of a humanized IgG1 anti-CD4 monoclonal antibody in the peripheral blood and synovial fluid of rheumatoid arthritis patients. Rheumatology (2000) 39(10):1139-46. doi:10.1093/rheumatology/39.10.1139

66. Choy E, Panayi GS, Emery P, Madden S, Breedveld FC, Kraan MC, et al. Repeat-cycle study of high-dose intravenous 4162 W94 anti-CD4 humanized monoclonal antibody in rheumatoid arthritis. A randomized placebo-controlled trial. Rheumatology (2002) 41(10):1142-8. doi:10.1093/ rheumatology/41.10.1142

67. Helling B, König M, Dälken B, Engling A, Krömer W, Heim K, et al. A specific CD4 epitope bound by tregalizumab mediates activation of regulatory T cells by a unique signaling pathway. Immunol Cell Biol (2015) 93(4):396-405. doi:10.1038/icb.2014.102

68. Czeloth N, Dälken B, Engling A, Osterroth F, Aigner S, Abufarag A, et al. Selective activation of naturally occurring regulatory $\mathrm{T}$ cells (Tregs) by the monoclonal antibody BT-061 as a novel therapeutic opportunity: pre-clinical and early clinical results. Ann Rheum Dis (2010) 69(Suppl3):99.

69. Becker C, Kubach J, Wijdenes J, Knop J, Jonuleit H. CD4-mediated functional activation of human CD4+CD25+ regulatory T cells. Eur J Immunol (2007) 37(5):1217-23. doi:10.1002/eji.200636480

70. Mellor AL, Munn DH. Physiologic control of the functional status of Foxp3+ regulatory T cells. JImmunol (2011) 186(8):4535-40. doi:10.4049/ jimmunol.1002937

71. Bopp T, Becker C, Klein M, Klein-Hessling S, Palmetshofer A, Serfling E, et al. Cyclic adenosine monophosphate is a key component of regulatory $\mathrm{T}$ cell-mediated suppression. J Exp Med (2007) 204(6):1303-10. doi:10.1084/ jem.20062129

72. Ng CM, Stefanich E, Anand BS, Fielder PJ, Vaickus L. Pharmacokinetics/ pharmacodynamics of nondepleting anti-CD4 monoclonal antibody (TRX1) in healthy human volunteers. Pharm Res (2006) 23(1):95-103. doi:10.1007/ s11095-005-8814-3

73. Dokoupilova E, Jeka S, Vencovsky J, Badurski J, Prins K, Strand V, et al. Use of a biologic marker for an integrated pharmacodynamic and clinical analysis to inform further clinical development, including dose selection for the Phase $2 \mathrm{~b}$ trial - Treat $2 \mathrm{~b}$ - of tregalizumab in rheumatoid arthritis. Arthritis Rheum (2013) 65(Suppl 10):1412.

74. Abufarag A, Aigner S, Czeloth N, Dälken B, Koch H, Niemann G, et al. Selective activation of naturally occurring regulatory $\mathrm{T}$ cells (Tregs) by the monoclonal antibody BT-061 as a novel therapeutic opportunity in psoriasis: early clinical results after single doses. J Invest Dermatol (2010) 130(Issue 2):S64.

75. Rudnev A, Ragavan S, Trollmo C, Malmstroem V, Becker C, Jonuleit H, et al. Selective activation of naturally occurring regulatory $\mathrm{T}$ cells (Tregs) by the monoclonal antibody (mAb) BT-061. Markers of clinical activity and early Phase II results in patients with rheumatoid arthritis (RA). Arthritis Rheum (2010) 62(Suppl 10):1125.

76. ClinicalTrials.gov. Study to Investigate the Safety and Efficacy of Tregalizumab in Subjects (MTX-IR) with Active Rheumatoid Arthritis (986) (2015). Available from: www.clinicaltrials.gov/show/nct01999192

77. van Vollenhoven RF, Keystone EC, Strand V, Pacheco-Tena C, Vencovsky J, Behrens F, et al. A Phase $2 \mathrm{~b}$ study evaluating the efficacy and safety of subcutaneously administered tregalizumab in subjects with active rheumatoid arthritis (RA) despite treatment with methotrexate (MTX). Arthritis Rheumatol (2015) 67(Suppl 10). Available from: http://acrabstracts.org/ abstract/a-phase-2b-study-evaluating-the-efficacy-and-safety-of-subcutaneously-administered-tregalizumab-in-subjects-with-active-rheumatoid-arthritis-ra-despite-treatment-with-methotrexate-mtx/

Conflict of Interest Statement: Martin König, Faiza Rharbaoui, Silke Aigner, Benjamin Dälken, and Jörg Schüttrumpf are employees of Biotest AG, Dreieich, Germany.

Copyright (C) 2016 König, Rharbaoui, Aigner, Dälken and Schüttrumpf. This is an open-access article distributed under the terms of the Creative Commons Attribution License (CC BY). The use, distribution or reproduction in other forums is permitted, provided the original author(s) or licensor are credited and that the original publication in this journal is cited, in accordance with accepted academic practice. No use, distribution or reproduction is permitted which does not comply with these terms. 